\title{
PETROFYZIKÁLNÍ CHARAKTERISTIKA HRANIČNÍHO INTERVALU DEVONU A KARBONU V MORAVSKÉM KRASU
}

\author{
Petrophysical signature of the Devonian/Carboniferous boundary interval in the Moravian Karst
}

Tomáš Kumpan', Ondřej Bábek ${ }^{1,2}$, Jiří Kalvoda ${ }^{1}$

1 Ústav geologických věd PřF MU, Kotlářská 2, 61137 Brno; e-mail: kumpan.tom@gmail.com

${ }^{2}$ Katedra geologie PřF UP, 17. listopadu 12, 77146 Olomouc

(24-41 Vyškov)

Key words: Famennian, Tournaisian, petrophysics, Líšeň Formation, Hangenberg Event

\begin{abstract}
The first results of the petrophysical research (gamma-ray spectrometry, magnetic susceptibility, diffuse spectral reflectance) of the Devonian/Carboniferous boundary interval in the southern and middle part of the Moravian Karst demonstrate a good correlation potential of outcrop logging by gamma-ray spectrometry. This method allows us to correlate distinct petrophysical patterns through the different lithofacies developments (Horákov and Hostènice facies), while magnetic susceptibility and diffuse spectral reflectance failed to show correlatable patterns. The most prominent petrophysical patterns at the sections can be correlated with the polyphase Hangenberg Event.
\end{abstract}

\section{Úvod}

Hranice mezi devonem a karbonem (D-C) je globálně doprovázena hromadným vymíráním, výraznými faciálními a geochemickými změnami či rozsáhlými hiáty v důsledku eustatických oscilací, označovaných jako hangenberský polyfázový event, spojený s krátkodobým zaledněním Gondwany (Isaacson et al. 2008). V jižní a střední části Moravského krasu je odkryt průběh hranice D-C ve dvou litofaciálních vývojích líšeňského souvrství (obr. 1). V mělkovodnějším hostěnickém vývoji je při D-C hranici patrna kondenzace a hiát, kdežto hlubokovodnější horákovský vývoj zahrnuje nepřerušený sled všech konodontových zón od famenu do tournai. $\mathrm{V}$ rámci současných snah Mezinárodní stratigrafické komise o redefinici problematicky stanovené hranice D-C a jejího stratotypu (La Serre, jižní Francie) vyvstala potřeba zpřesnit biostratigrafické korelace kombinací sekvenčně-stratigrafických, geochemických a petrofyzikálních metod. Na lokalitách Lesní lom, Mokrá-východ a Křtiny (obr. 2) byly vybrány

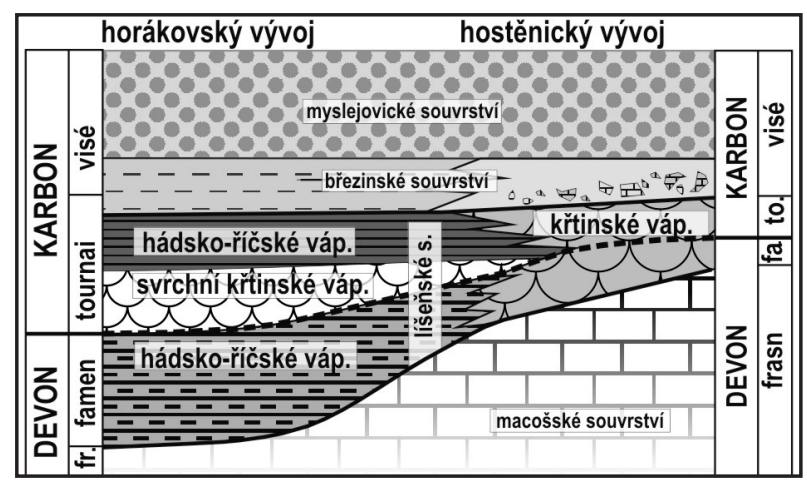

Obr. 1: Stratigrafické schema paleozoika Moravského krasu (podle Reze et al. 2011).

Fig. 1: Stratigraphic diagram of the Moravian Karst Palaeozoic (after Rez et al. 2011).

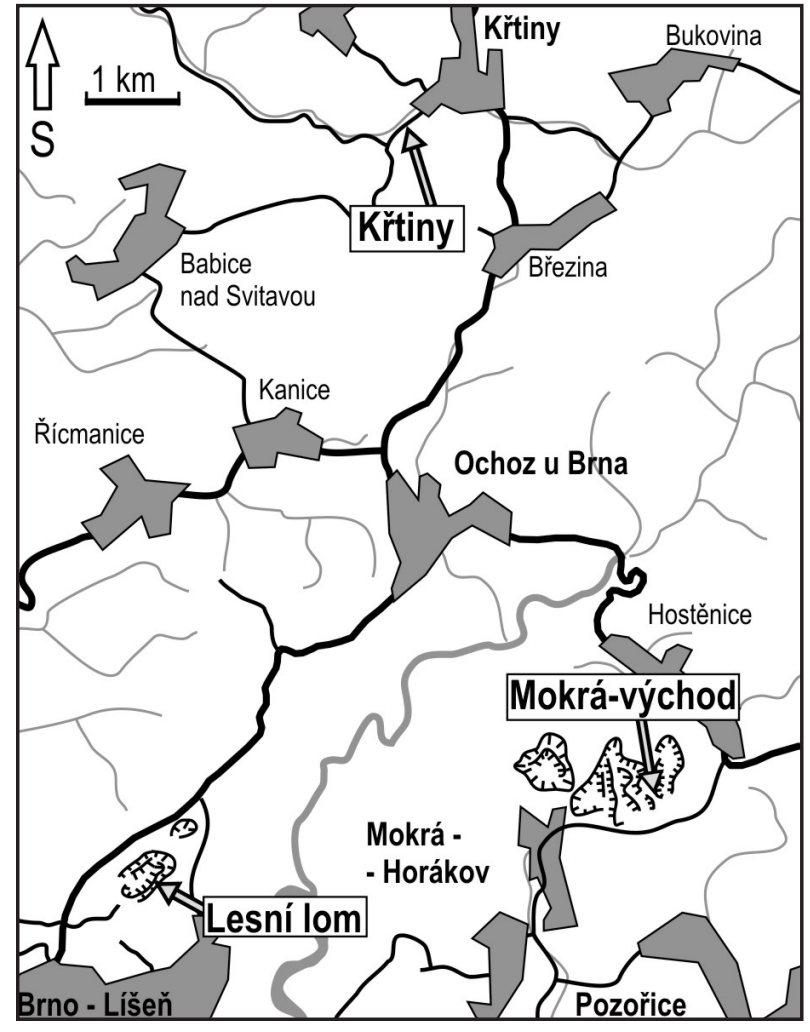

Obr. 2: Lokalizace studovaných profilù.

Fig. 2: Localization of the studied sections.

profily pro vypracování vysoce rozlišující integrované stratigrafie, jejíz kličovou součástí jsou petrofyzikální metody - terénní gamaspektrometrie (GRS), hmotnostně specifická magnetická susceptibilita (MS) a spektrometrie difuzního odraženého světla (DRS). GRS a MS mohou reprezentovat proxy parametry klastické př́měsi $\mathrm{v}$ karbonátech a tak indikovat prínos terigenního materiálu do karbonátového systému nebo rychlost produkce karbonátu (Rider 1999, 


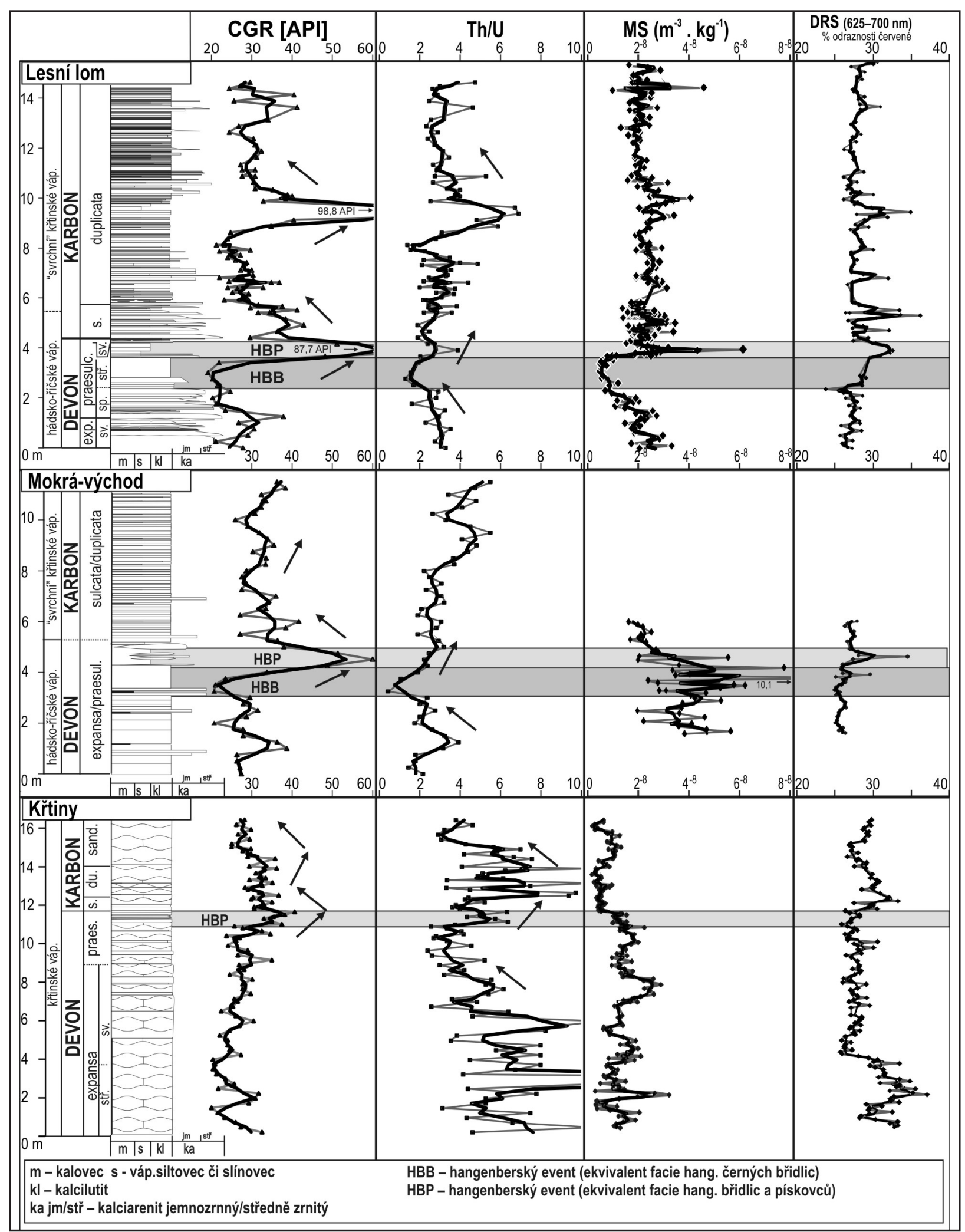

Obr. 3: Litologická a petrofyzikální schemata studovaných profilů. Fig. 3: Lithologic and petrophysical logs of the studied sections.

Ellwood et al. 1999). DRS může indikovat míru oxidace dna nebo redox potenciál $\mathrm{v}$ sedimentu během rané diageneze (Koptíková et al. 2010). Cílem práce bylo 1.) zjištění petrofyzikálních vlastností hraničního intervalu D-C, od svrchního famenu do spodního tournai, v obou zmíněných faciálně odlišných vývojích jižní a stř̌ední části
Moravského krasu, 2.) určení jejich trendů a 3.) ověření jejich potenciálu pro zpřesnění biostratigrafické korelace.

\section{Metody}

Pro terénní GRS měření byl použit gamaspektrometr Exploranium RS-230 Super Spec (Radio Solutions 
Inc.) s BGO detektorem $2^{\prime \prime} \times 2$ “. Profily byly měřeny $\mathrm{s}$ pravidelným vertikálním krokem $(25 \mathrm{~cm})$ a dobou měření $180 \mathrm{~s} v$ každém bodě. Naměřené koncentrace $\mathrm{K}(\%), \mathrm{U}(\mathrm{ppm})$ a Th (ppm) byly přepočítány na hodnoty CGR (Clay Gamma Ray), používané v naftovém průmyslu, které lépe odrážejí přítomnost jílů, dle vzorce CGR $[\mathrm{API}]=\mathrm{Th}[\mathrm{ppm}]{ }^{\star} 3,93+\mathrm{K}[\%]^{\star} 16,32$ (Rider 1999). Sledován byl také poměr Th/U, odrážející redoxní podmínky v sedimentu. Pro MS a DRS byly odebrány vzorky čerstvé horniny (15-60 g) bez výrazných alterací či žilkování, v pravidelném vertikálním kroku 3 až $10 \mathrm{~cm}$. MS byla měřena na laboratorním kapamůstku KLY-4 (Agico, s. r. o., intenzita magnetického pole $300 \mathrm{Am}^{-1}$, frekvence $920 \mathrm{~Hz}$, citlivost $4 \times 10^{-8} \mathrm{SI}$ ) a je vyjádřena $\mathrm{v} \mathrm{m}^{3} \cdot \mathrm{kg}^{-1}$. DRS byla naměřena na čerstvých a rovných lomných plochách vzorků ručním spektrálním fotometrem SP-62 (X-Rite, USA). Výsledkem měření je křivka odraznosti ve vlnově délkovém pásmu 400-700 nm s krokem $10 \mathrm{~nm}$ a kolorimetrické parametry $L^{*} a^{*} b^{*} v$ barevném prostoru CIE $L^{\star} a^{\star} b^{*}$ (Comission Internationall'Eclairage). Procenta odraznosti jednotlivých spekter (vyobrazeny křivky odraznosti červené; 625-700 nm) byla normalizována k celkové odraznosti. Píky prvních derivací odraznostní křivky byly použity pro semikvantitativní zjištění množství goethitu (425-445 a $525-535 \mathrm{~nm})$ a hematitu $(565-575 \mathrm{~nm}$ ) (Barranco et al. 1989).

\section{Litologie a petrofyzikální data Lesní lom $\left(49^{\circ} 13^{`} 18^{\prime \prime} N\right.$; $\left.16^{\circ} 41^{\prime} 46^{\prime \prime} E\right)$}

Hraniční D-C profil v horákovském vývoji je odkryt v Lesním lomu na kontaktu hádsko-ř́íčských a „svrchních“ křtinských vápenců (obr. 2 a 3). Významný je z hlediska nepřerušeného sledu hraničních konodontových zón, studovaných v rozsahu od svrchní Palmatolepis gracilis expansa až do svrchní Si. duplicata, o celkové mocnosti $15 \mathrm{~m}$. GRS hodnoty jsou ve svrchnofamenské části profilu s hádsko-říčskými vápenci ( 0 až 3,4 m; zóna sv. Pa. gr. expansa až stř. Si. praesulcata) nízké (průměr CGR 24,7 API) a jeví do nadloží klesající trend, který kulminuje v poloze laminovaného kalcilutitu (tzv. „laminit“; 2,5 až 3,4 m; CGR

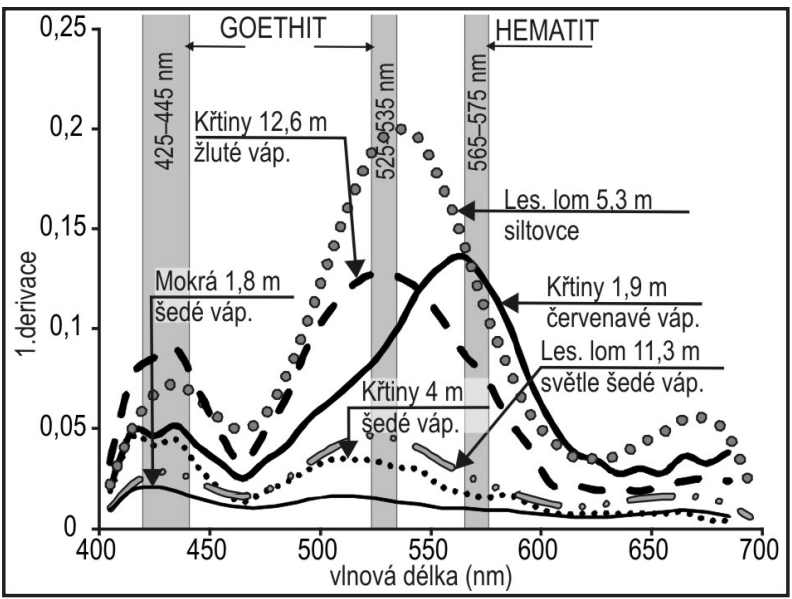

Obr. 4: První derivace spektrálně odraznostních křivek z vybraných vzorků.

Fig. 4: First derivatives of spectral reflectance curves from selected samples.
20,3 API) s výrazně nízkým poměrem Th/U (<2; s minimem 1,29). Kalovce s čočkami vápenců a vápnité siltovce v nadloží laminitu (3,4 až 4,2 m; zóna stř. Si. praesulcata) jsou doprovázeny výrazným píkem (CGR 87,72 API), který je následován do nadloží pozvolna klesajícím trendem v rámci výrazně heterolitického sledu kalciarenitů, kalcilutitů a siltovců (4,2-8,6 m; sv. Si. praesulcata - Si. duplicata). Další výrazný kladný pík hodnot CGR (98,8 API) a koncentrací K a Th se objevuje v intervalu 8,6-10,0 m, v polohách $\mathrm{s}$ větším podílem kalovcových a siltovcových poloh (zóna Si. duplicata). Na křivce magnetické susceptibility se projevuje skok od nízkých do vysokých hodnot SI těsně na hranici mezi laminitem $\left(1,1 \times 10^{-9}\right)$ a nadložními kalovci $\left(5,7 \times 10^{-8}\right)$, který je korelovatelný se záznamem CGR. DRS křivka je při bázi $(0,0-3,4 \mathrm{~m})$ v nízkých hodnotách, nad laminitem dochází $\mathrm{k}$ nevelkému nárůstu s několika drobnými píky v polohách siltovců (obr. 3). DRS signál je ř́zen goethitem (obr. 4).

\section{Mokrá - východ $\left(49^{\circ} 13^{\prime} 44^{\prime \prime} N ; 16^{\circ} 46^{\prime} 8^{\prime \prime} E\right)$}

Další odkryv hranice $\mathrm{D}-\mathrm{C} \mathrm{v}$ horákovském vývoji byl zastižen v lomu Mokrá-východ, kde byl studován $\mathrm{v}$ mocnosti 11,5 m (obr. 2 a 3). Sled je v překocené pozici a výrazněji tlakově deformován. Konodontové fauny jsou zde poměrně chudé a doposud nebyly nalezeny klíčové druhy pro jemnější biostratigrafické rozčlenění. Faciálními změnami je profil velmi podobný lokalitě Lesní lom, zastoupeny jsou však jemnozrnnější facie. Trendy GRS křivek jsou téměř totožné s profilem v Lesním lomu. Ve spodní části studovaného profilu (0,0-3,7 m), v hádsko-řričských vápencích (?zóna Pa. gr. expansa s.l. - Si. praesulcata s. 1.), má GRS klesající trend s kulminací v intervalu s černými břidlicemi a laminitem (CGR 20,8 API). Koncentrace uranu zde však dosahuje svého maxima (6,6 ppm), což se projevuje také na nízkém poměru Th/U (min. 0,42$)$. Nadložní siltovcová poloha s čočkami kalcilutitů $(4,0-5,0 \mathrm{~m})$ má pozitivní pík CGR (60,3 API) s následným klesajícím trendem do tournaiských křtinských vápenců. $\mathrm{V}$ intervalu 8,25-11,5 m GRS mírně vzrůstá. MS má vzrůstající hodnoty s velkými oscilacemi na bázi profilu, s maximy v laminitu $\left(1,1 \times 10^{-7}\right)$. Nadložní sekvence má sestupný trend. DRS hodnoty mají stejný charakter jako v Lesním lomu (obr. 3 a 4 ).

\section{Křtiny $\left(49^{\circ} 17^{`} 37^{\prime \prime} N ; 16^{\circ} 44^{`} 6^{\prime \prime} \mathrm{E}\right)$}

D-C hraniční interval v hostěnickém faciálním vývoji je odkryt v lomu u Křtin (obr. 1 a 2), kde byl studován v mocnosti $16 \mathrm{~m}$, v rozsahu od zóny střední $\mathrm{Pa}$. gr. expansa do zóny Siphondella sandbergi (obr. 3). V celé mocnosti se jedná o monotónní, více či méně hlíznaté, převážně lavicovité kalcilutity. Při bázi měřeného profilu, v červenavých kalcilutitech zóny stř. $P a$. gr. expansa, jsou GRS hodnoty nejnižší (CGR 20,7 API) a s pravidelnými oscilacemi rostou do šedých vápenců zóny spodní Si. praesulcata. Červenavé vápence mají výrazně oscilující poměr Th/U ( 4 až >7), který do nadložních šedých vápenců mírně klesá až k nejvyšším famenským polohám. Na úplném závěru famenského sledu $(10,7-11,4)$ jsou kalcilutity silně hlíznaté a GRS zde dosahuje nejvyšších hodnot (CGR 40,35 API). 
V zóně Si. sulcata a Si. duplicata $(11,4-12,5)$ je patrný klesající trend. Uvnitř zóny Si. duplicata $(12,5-14,1)$ dochází k mírnému nárůstu CGR (35,91 API) a Th (5,4ppm), které do zóny Si. sandbergi opět klesají. MS signál je ve famenské části vyšší ( $\mathrm{v}$ průměru $1,4 \times 10^{-8}$ ), na bázi tournai dochází ke skokovému snížení (průměr $6,1 \times 10^{-9}$ ). DRS hodnoty jsou v červenavých kalcilutitech při bázi profilu (0,0-3,1 m) vysoké, řízené hematitem, a v šedých vápencích (3,8-11,2 m) nižší, řízené goethitem (obr. 3 a 4).

Nejvyšší statistickou korelaci s dávkovým příkonem (TOT; nGy.kg-1) má na většině profilů Th (tab. 1). V Lesním lomu je poměrně dobrá korelace mezi Th a $K\left(R^{2}=0,7\right)$. Slabší je na Mokré $\left(\mathrm{R}^{2}=0,57\right)$ a nízká ve Křtinách $\left(\mathrm{R}^{2}=\right.$ 0,27) (tab. 1).

\section{Diskuze a závěr}

Vůbec poprvé byly studovány petrofyzikální poměry D-C hraničního intervalu v horákovském a hostěnickém vývoji líšeňského souvrství Moravského krasu. Největší korelační potenciál z použitých metod má GRS. Z př̀vládajících vyšších statistických korelací mezi dávkovým príkonem a thoriem (tab. 1) vyplývá, že GRS signál je řízen především tímto prvkem. Statistické korelace koncentrací $\mathrm{K}$ a Th (tab. 1) vykazují poměrně vysoké hodnoty koeficientu lineární regrese na profilech Lesní lom a Mokrá

\begin{tabular}{|l|c|c|c|c|c|}
\hline Profil & $\begin{array}{c}\text { Počet } \\
\text { měrení }\end{array}$ & $\begin{array}{c}\mathbf{R}^{2} \\
(\mathrm{TOT} \text { a K })\end{array}$ & $\begin{array}{c}\mathbf{R}^{2} \\
(\mathrm{TOT} \text { a U) }\end{array}$ & $\begin{array}{c}\mathbf{R}^{2} \\
(\mathrm{TOT} \text { a Th })\end{array}$ & $\begin{array}{c}\mathbf{R}^{2} \\
(\mathrm{Th} \text { a K })\end{array}$ \\
\hline Lesní lom & 85 & 0,80 & 0,41 & 0,92 & 0,70 \\
\hline Mokrá & 47 & 0,43 & 0,45 & 0,46 & 0,57 \\
\hline Křtiny & 84 & 0,56 & 0,36 & 0,71 & 0,27 \\
\hline
\end{tabular}

Tab. 1: Statistické údaje z gamaspektrometrických měření. Koeficient lineární regrese $\left(\mathrm{R}^{2}\right)$ mezi celkovým dávkovým př́konem (TOT) a K, U, Th a mezi K a Th.

Tab. 1: Statistics of the gamma-ray spectrometry measurements. The linear regression coefficient $\left(\mathrm{R}^{2}\right)$ between the total dose rate (TOT) and $\mathrm{K}, \mathrm{U}$, Th and between $\mathrm{K}$ and $\mathrm{Th}$.
$\left(\mathrm{R}^{2}=0,7\right.$ a 0,57$)$. Výjimkou je profil Křtiny $\left(\mathrm{R}^{2}=0,27\right)$. To indikuje, že obsahy $\mathrm{K}$ a Th se ve vápencích mění prímo úměrně a jsou vázané na stejné nosiče. Těmi jsou pravděpodobně jílové minerály (zejména illit), které obsahují K ve své strukturní mřižce a typicky adsorbují Th na svém povrchu (Rider 1999). Variabilita K a Th potom indikuje rozředění obou prvků $\mathrm{v} \mathrm{CaCO}_{3}$ a lze ji tedy interpretovat jako obsah jílu ve vápencích. Toto pozorování je v souladu s běžnou interpretací $\mathrm{K}$ a Th v gamakarotáži jako indikátoru jílovitosti /shaliness/ (Rider 1999). V horákovském vývoji lze na základě GRS detailně korelovat profily bez stratigraficky průkazných konodontů (Mokrá-východ) s biostratigraficky dobře datovanými profily (Lesní lom). Generelní GRS trendy pak umožňují korelaci mezi profily z faciálně odlišných vývojů (obr. 5). Těmito trendy jsou nízké hodnoty v sekvenci od zóny $P a$. gr. expansa do zóny stř. Si. praesulcata, skokové zvýšení od vyšší části zóny stř./ sv. Si. preasulcata na první GRS pík, od kterého hodnoty v průběhu zón Si. sulcata s Si. duplicata klesají až k druhému GRS píku uvnitř zóny Si. duplicata.

Zvýšené množství hematitu (zjištěné prostřednictvím DRS) v červenavých vápencích zóny stř. $P a$. $g r$. expansa na lokalitě Křtiny může mít raně diagenetický původ a odrážet dobře prokysličené dno, což může být také příčinou variabilního, poměrně vysokého poměru Th/U (>7) (srov. Koptíková et al. 2010). Výše, v šedých kalcilutitech zóny sv. Pa. gr. expansa a sp. Si. praesulcata, poměr Th/U klesá, zřejmě jako odraz poklesu dnové oxicity. Zóna stř. Si. praesulcata ve Křtinách chybí, což indikují petrofyzikální (obr. 5) i geochemické korelace (Kumpan et al. 2012). Tato zóna je však zastoupena v Lesním lomu polohou laminitu, kde je velice nízký poměr Th/U $(<2)$, odrážející možné redukční prostředí (Adams - Weaver 1958). To společně se zjištěnou pozitivní odchylkou $\delta^{13} \mathrm{C}$ (Kumpan et al. 2012), dokumentovanou ze zóny stř./sv. Siphonodella preasulcata např. také z Rakouska a Německa (Kaiser et al. 2006), podtrhuje př́slušnost laminitu

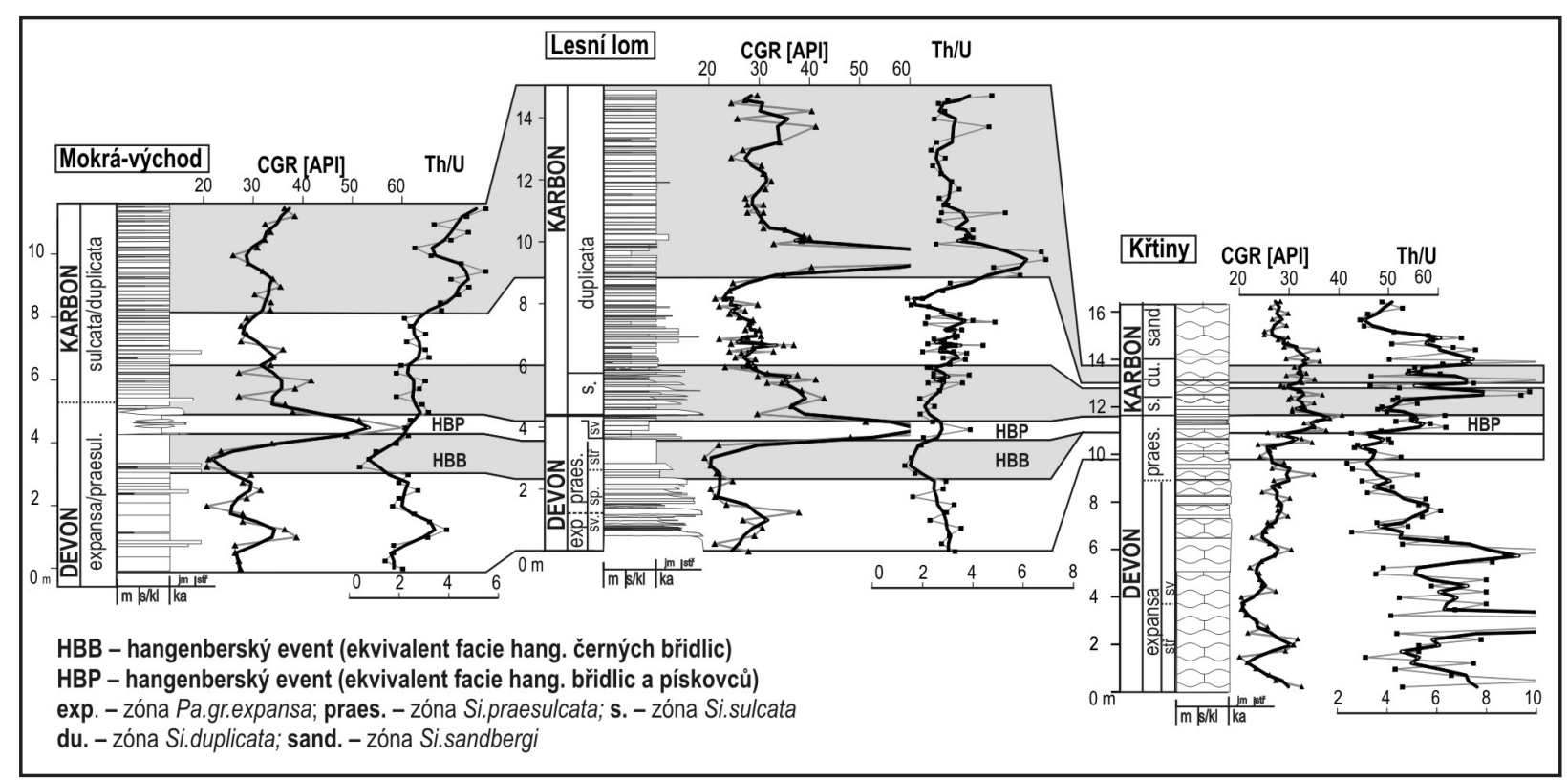

Obr. 5: Gamaspektrometrická korelace (CGR[API] a Th/U) studovaných profilů.

Fig. 5: Gamma-ray spectrometry correlation (CGR [API] and Th/U) of the studied sections. 
k hlavní anoxické fázi hangenberského eventu (ekvivalent facie černých hangenberských břidlic; obr. 3). Maximum GRS hodnot v nejvyšší části zóny stř. Si. praesulcata a sv. Si. praesulcata může být spojené s poklesem karbonátové produkce po hangenberské biotické krizi či s možnou progradací jemného siliciklastického materiálu, dokládající časovou ekvivalenci s facií hangenberských pískovců (Kalvoda - Kukal 1987). MS křrivky nelze mezi jednotlivými profily detailněji korelovat a zřejmě odráží pozdější diagenetické přeměny magnetických minerálů.

\section{Poděkování}

Tento výzkum byl financován z grantu GAČR „Hranice devonu a karbonu v Evropè - multidisciplinární přistup“ (P210/11/1891). První autor je stipendista programu Brno Ph.D. talent - financuje statutární mèsto Brno.

\section{Literatura}

Adams, J. A . - Weaver, C. E. (1958): Thorium-to-uranium ratios as indicators of sedimentary processes; example of concept of geochemical facies. - American Association of Petroleum Geologists Bulletin, 42, 387-430.

Barranco, F. T. - Balsam, W. L. - Deaton, B. C. (1989): Quantitative reassessment of brick red lutites; evidence from reflectance spectrophotometry. - Marine Geology, 89, 299-314.

Ellwood, B. B. - Crick, R. E. - El Hassani, A. (1999): The magneto-susceptibility event and cyclostratigraphy (MSEC) method used in geological correlation of Devonian rocks from Anti-Atlas Morocco. - American Association of Petroleum Geologists Bulletin, 83, 1 119-1 134.

Isaacson, P. E. - Díaz-Martínez, E. - Grader, G. W. - Kalvoda, J. - Babek, O. - Devuyst, F. X. (2008): Late Devonian-earliest Mississippian glaciation in Gondwanaland and its biogeographic consequences. - Palaeogeography, Palaeoclimatology, Palaeoecology, 268, 126-142.

Kaiser, S. I. - Steuber, T. - Becker, T. R. - Joachimski, M. M. (2006): Geochemical evidence for major environmental change at the Devonian-Carboniferous boundary in the Carnic Alps and the Rhenish Massif. - Palaeogeography, Palaeoclimatology, Palaeoecology, 240, 146-160.

Kalvoda, J. - Kukal, Z. (1987): Devonian-Carboniferous Boundary in the Moravian Karst at Lesní lom Quarry, Brno-Líšeň, Czechoslovakia. - Courier Forschungsinstitut Senckenberg, 98, 95-117.

Koptíková, L. - Bábek, O. - Hladil, J. - Slavík, L. (2010): Stratigraphic significance and resolution of spectral reflectance logs in Lower Devonian carbonates of the Barrandian area, Czech Republic; a correlation with magneticsusceptibility and gamma-ray logs. - Sedimentary Geology, 225, 83-98.

Kumpan, T. - Kalvoda, J. - Bábek, O. - Frýda, J. (2012): Izotopové záznamy uhlíku přes hangenberský event (hranice devon-karbon) ve střední a jižní části Moravského krasu. - Zprávy o geologických výzkumech v roce 2011, 26-28.

Rez, J. - Melichar, R. - Kalvoda, J. (2011): Polyphase deformation of the Variscan accretionary wedge: an example from the southern part of the Moravian Karst (Bohemian Massif, Czech Republic). - Kinematic Evolution and Structural Styles of Fold-and-Thrust Belts. Geological Society London, Special publications 349, 223-235.

Rider, M. H. (1999): The Geological Interpretation of Well Logs. - Whittles Publishing Services. 